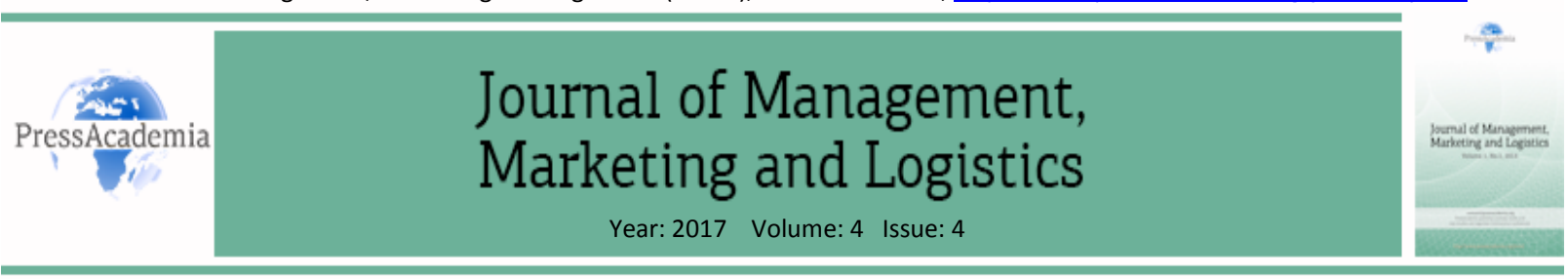

\title{
AN APPLIED STUDY ON THE CUSTOMER RETENTION DYNAMICS OF ORGANIZED READY-TO-WEAR TEXTILES RETAILERS IN REAL AND VIRTUAL MARKETS IN TURKEY
}

\author{
DOI: 10.17261/Pressacademia.2017.726 \\ RJBM-V.4-ISS.4-2017(6)-p.366-383
}

\section{Kemal Ozkan Yilmaz, Murat Ferman}

Işık University, Institute of Social Sciences, İstanbul, Turkey. kyilmaz95@gmail.com Işık University, School of Business, İstanbul, Turkey. murat.ferman@isikun.edu.tr

\section{To cite this document}

Yilmaz, K.O., Ferman, M. (2017). An applied study on the customer retention dynamics of organized ready-to-wear textiles retailers in real and virtual markets in Turkey. Journal of Management, Marketing and Logistics (JMML), V.4, Iss.4, p.366-383.

Permemant link to this document: http://doi.org/10.17261/Pressacademia.2017.726

Copyright: Published by PressAcademia and limited licenced re-use rights only.

\begin{abstract}
Purpose - This descriptive field study aims to reveal customer retention strategy formulation insights among top level marketing professionals of the organized ready-to-wear textiles retailers, who are members of United Brands Association (BMD) both active in off-line and online channels, in the Turkish market.

Methodology - Regarding the literature review conducted a research model with seven variables was proposed, and depending on the proposed research model, six hypotheses were formulated. The research is conducted by a questionnaire which has been applied on-line, by e-mail, post; which is designed specifically to test the proposed relationships, namely the hypotheses constructed. Factor analysis has been conducted to reveal the dimensionality of the variables in the research model. In this regard, principle component analysis using Varimax rotation was performed and the reliabilities of the scales have been assessed by alpha coefficient. Depending on the results of the factor analysis, correlation and regression analyses have been used to test the hypotheses of the study.

Findings - Results indicate that perceived product quality, service support and complaint handling, customer experience and suggestions provided and perceived price fairness have significant and positive effects on customer satisfaction. Furthermore, customer satisfaction, trust towards service provided, trust towards company and brand, corporate reputation and corporate social responsibility have significant and positive effects on customer retention.

Conclusion - The outcomes and findings of the study were found to support the objectives of the study and the results of the statistical analysis were found to accept hypotheses of the study. Perceived product quality, perceived service quality, perceived price fairness, trust and corporate image are some vital challenges for customer retention.
\end{abstract}

Keywords: Customer retention, customer satisfaction, trust, corporate image, organized ready-to-wear textile retailers in Turkey. JEL Codes: M31, M30, M10

\section{INTRODUCTION}

Customer retention (CR) is the set of activities an organization undertakes in order to reduce customer defections. Companies can boost profits by almost 100 percent by retaining just 5 percent more of their customers (Reichheld and Sasser, 1990, p.105). Rust and Zahorik (1993), Reichheld (1996), and Mcllroy and Barnett (2000, p. 347) have highlighted that the financial implications of attracting new customers may be five times as costly as keeping existing customers. The current literature mainly concentrates only on consumers' perspective and question their point of view. This study's originality comes from being the pioneer attempt to bring out an effective model to formulate customer retention strategies in ready-to-wear textile sector in Turkey. The aim of this descriptive field research is to uncover and have a better understanding about the marketing related factors influencing customer retention strategies used by organized ready-towear textile retailers, based on marketing professionals' insights whose companies are members of United Brands Association (BMD) that are both active in offline and online channels. The proposed model in the dissertation is designed a after through literature review to explore the factors that are capable of defining the variables in the hypotheses constructed and determine the relationship between the extracted factors and the ways they interact with each other. The research attempts to obtain tangible conclusions with its adjusted research model based on the findings of the field survey which has been applied on-line. 


\section{LITERATURE REVIEW}

\subsection{Customer Relationship Management, Customer Loyalty and Customer Retention}

In contemporary marketing practice Customer Relationship Management (CRM) is seen as an excellent marketing discipline with the mission of establishing a long-term relationship between the company and customers through which both sides win better value (Pepić and Duman, 2015, p.225). Rowe and Barnes (1998 cited in O'Malley and Tynan, 2000, p.801) identify what they consider to be four tangible manifestations of Relationship Marketing (RM) in consumer markets: (1) Locking in customers (cf. Barnes, 1994; Turnbull and Wilson, 1989; Palmer, 1995), (2) Customer retention (CR) (cf. Berry, 1983), (3) Database marketing (Copulsky and Wolf, 1990; Tracy and Wiersema, 1993), and (4) Close personal relationships (cf. Barnes, 1994; 1995). The relationship between customer loyalty and satisfaction, profitability and customer retention is described within the framework of relationship marketing (Mcllroy and Barnett, 2000, p.p. 347). Kotler et al. (2003) clearly highlights that winning companies are more productive in acquiring, keeping, and growing customers. The hierarchical structure that, Ziethalm and Bitner (2000, p. 140) describe between acquiring, satisfying, retaining and enhancing customers has been used as the main distinction in this study. The role of CRM is to assist firms in leveraging "the information and experience in acquisition, development and retention of a profitable customer portfolio," which Wayland and Cole (1997, p. 32) call customer knowledge management. Ranaweera and Parabhu's (2003) CR definition highlighting "future propensity of a customer to stay with the service" are in line with Zeithalm's (1996) "future behavioral intentions", the target is to sustain future customer portfolio. Relationships conducted via online channel tools are also under focus. Mcllroy and Barnett (2000, p. 348) define customer loyalty as "a customer's commitment to do business with a particular organization, purchasing their goods and services repeatedly, and recommending the services and products to friends and associates". Virtual communities are a platform to share information between members or customers. Sands (2003 cited in Nikhashemi et al., 2013, p.82) describe online community as one e-group where the members receive the messages or emails posted and replied by other members in the group. Customers, who have used the product or the service, can use blogs, company sites, or other online platforms to share useful information which are also a source for companies to collect customer feedback and market their brands, products and services.

Customer retention has a direct impact on profitability and past research has claimed that it can be five times more expensive to obtain a new customer than to retain one Haywood (1989, cited in Mcllroy and Barnett, 2000, p. 347). "As a customer's relationship with the company lengthens, profits rise. And not just a little. Companies can boost profits by almost 100 percent by retaining just 5 percent more of their customers (Reichheld and Sasser, 1990, p.105). Gan,

Stum and Thiry (1991, cited in Gan, Cohen, Clemes, and Chong, 2006, p.84) argue that, retained customers do demonstrate immunity to competitive pull. This is supported by Strandvik and Liljander (1994) in an exploratory study of customer relationship strength.

\subsection{Perceived Service Quality}

Daughtrey, Vowles, and Black (2013, p.294) also support that service quality based satisfaction results in loyalty. Furthermore it was found that service organization employees form particularly close relationships with customers because employees and customers often work together in the creation of many services, where services are produced by employees and consumed by customers simultaneously (Lovelock, 1981; Berry, 1980, cited in Gan et al., 2006, p.88). Thus, employees actually become a part of the service. Aflaki and Popescu (2013) focus on managing service, as they evaluate it as a more effective driver of customer retention than prices; and they refer to supportive findings of Liu (2007), and Pfeifer and Ovchinnikov (2011). Potter-Brotman (1994, pp.55-56) concludes that "everyone who interacts with customers must become an active agent for customer retention." Parasuraman, Zeithalm and Berry (1985, cited in Shahin, n.d., p.2) proposed that ten dimensions determine service quality: reliability, responsiveness, competence, access, courtesy, communication, credibility, security, understanding/knowing the customers, and tangibles. Thus, they proposed that the differences between perceived performance and expected performance of these ten dimensions determine overall perceived service quality.

Brady and Cronin (2001, pp.34-49) has gathered remarkable previous studies on perceived service quality in the co-joint article. The conceptualizations are given in Figure 1 . The best thing a company can do is to make it easy for the customer to complain. Suggestion forms, toll-free numbers, web sites, and e-mail addresses allow for quick, two-way communication (Kotler and Keller, 2006, p. 155). 


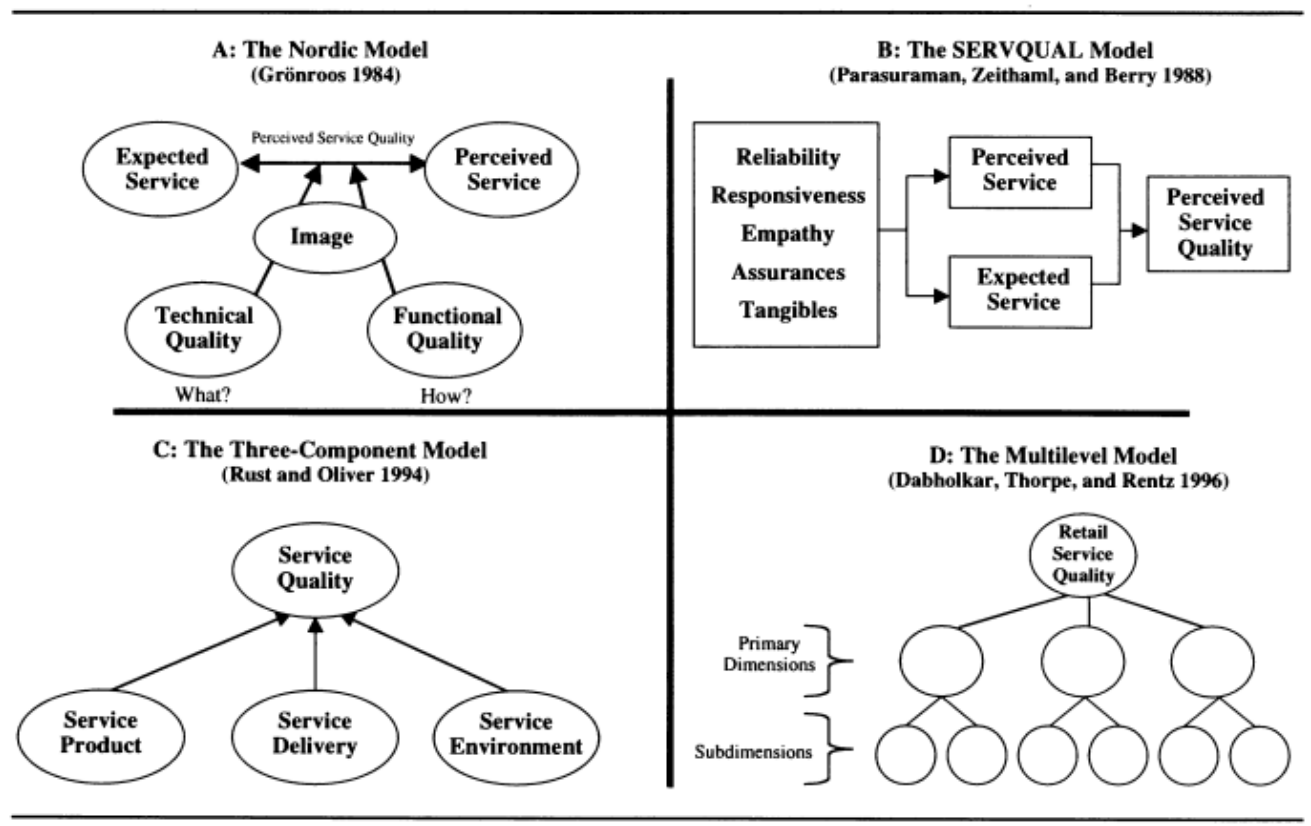

Source: Brady, M.K., Cronin, Jr.J.J., 2001. Some New Thoughts on Conceptualizing Perceived Service Quality: A Hierarchical Approach. The Journal of Marketing, Vol. 65, No. 3, p.35

Figure 1, Panel A identifies two service quality dimensions: functional quality represents how the service is delivered; that is, it defines customers' perceptions of the interactions that take place during service delivery. Technical quality reflects the outcome of the service act, or what the customer receives in the service encounter. Panel B, which views service quality as the gap between the expected level of service and customer percep-tions of the level received. Panel C: Offer a threecomponent model: the service product (i.e., technical quality), the service delivery (i.e., functional quality), and the service environment. Panel D: Because of the reports of SERVQUAL's inconsistent factor structure, Dabholkar, Thorpe, and Rentz (1996) identify and test a hierarchical conceptualization of retail service quality that proposes three levels: (1) customers' overall perceptions of service quality, (2) primary dimensions, and (3) subdimensions (Brady and Cronin, 2001).

\subsection{Perceived Product Quality}

Gumesson (2002) argues that perceived quality is the value of the customers' experiences with the product/service that is important to consider when developing products and services. Hinterhuber, Matzler (1998) and Buttle (2008) highlight Kano's (1984) product quality model that distinguishes between three forms of quality. Basic qualities are those that the customer routinely expects in the product. The second form is linear quality. These are attributes of which the customer wants more or less. The third form is attractive quality. These are attributes that surprise, delight and excite customers. Further studies developed Kano's model (1984) developed into 5 types of different product requirements: (1) Attractive quality, (2) One-dimensional quality, (3) Must-be quality, (4) Indifferent quality: respondent's saying is "I can live with it that way" in others words has no difference, (5) Reverse quality: respondent's saying is "I dislike it that way" (Wu, Tang and Shyu, 2010).

\subsection{Price Fairness}

In business markets, value "is the worth in monetary terms of the technical, economic, service, and social benefits a customer company receives in exchange for the price it pays for a market offering" (Anderson and Narus, 1998, p. 54). The clearer the pricing policy is, the higher the price receptiveness; a difficult task for manufacturers given the sensitiveness of customers and the current strong competition (Preikschas, Cabanelas, Rüdiger, and Lampón, 2017, p.415). Ranaweere and Neely (2003) support the hypothesis that the better the perceived price is, the greater is the level of repurchase intentions.

\subsection{Customer Satisfaction}

Gustafsson, Johnson and Roos (2005, p.210) define customer satisfaction as: a customer's overall evaluation of the performance of an offering to date (Johnson and Fornell 1991). Askhay (2007) developed an e-satisfaction model, which 
consists of five major contexts; under these five contexts there are eighteen factors that influence e-satisfaction. These five contexts are convenience, merchandising, site design, security and serviceability. As Danesh, Nasab, and Ling (2012, p.142) stated "The literature review recognized customer satisfaction has traditionally been regarded as a most important characteristic of long-term customer behavior (Oliver, 1980; Yi, 1990). The more satisfied customers are, the greater is their customer retention (Anderson and Sullivam, 1993; Fornell, 1992; Lee et al., 2001; Ranaweera and Prabhu, 2003). In a study by Cronin and Taylor (1992) and Patterson et al. (1997), it is recognized that customer satisfaction has a meaningful and positive effect on the repurchasing of a customer in a special classification of services. It is expressed by a team of researchers that customer satisfaction is an indisputable manner in determining the degree of customer retention for the current buyers in the professional services (Day et al., 1988). It is also reiterated by Day et al. (1988) and Kotler (1994) that the customer satisfaction is a significant factor to customer retention".

\subsection{Trust}

Fukuyama (1995) defines mutual trust as a kind of social capital. Customer trust is likely to be a strong driver of customer retention (Ranaweera and Prabhu, 2003). Mayer, Davis and Schoorman (1995, cited in Danesh, Nasab and Ling, 2012, p.142) define trust as "the willingness of a party to be vulnerable to the actions of another party based on the expectation that the other will perform a particular action important to the trustor. Trust is developed successively as a result of gradual dependence on the relationship resulting from mutual adaptation to the other party's needs (Gounaris, 2003).

\subsection{Corporate Image}

According to Barich and Kotler (1991), the corporate image describes how the public views the company's goodwill toward society, employees, customers, and other stakeholders. Their holistic image framework is composed of corporate social conduct, corporate contributions conduct, corporate employees conduct, company brand conduct, product, salesforce, communications, distribution channels, service, support and price. Accordingly, a number of factors such as quality products, quality services and reasonable prices are deemed to influence value judgement (Gan et al., 2006, p.86). Kotler (2003, p.206) states that, "The consumer develops a set beliefs about where a set of beliefs about where each brand stands on each attribute. The set of beliefs about a brand make up the brand image. The consumer's brand image will vary with his or her experiences as filtered by the effects of selective perception, selective distortion and selective retention". A person's image of a certain brand also contributes to its corporate image.

According to Grönroos (1990, cited in Akbar, 2013, p.46) “(corporate) image is a filter which influence the perception of the operation of the company". Corporate image is considered a sum of beliefs, ideas, and impressions that the customer has of a firm; which can be the result of experiences with purchasing and consuming goods or of information consumers extracted from their surroundings (Nguyen, Leclerc, and LeBlanc, 2013, p. 98). Bitner (1990) proposes that cues from the physical environment are instrumental in communicating the firm's purpose and image.

\section{DATA AND METHODOLOGY}

The study aims to measure the respondents' (top managers) attitudes towards customer satisfaction and customer retention. Depending on the literature survey conducted the effects of perceived product quality, perceived service quality and perceived price fairness on customer satisfaction is examined. Due to the importance of customer retention for the companies, in the next step the effects of customer satisfaction, trust and corporate image on customer retention are analysed. In other words, the study aimed to draw a picture of the factors that affect customer satisfaction and finally customer retention. In this regard, it is proposed that the findings of the study will shed light on marketing managers' customer satisfaction and retention strategies by revealing the factors that lead customer satisfaction and customer retention.

The study population is selected members of the United Brands Association (BMD), who are organized ready-to-wear retailers operating both in real and virtual markets (with their own website). They form the target population of the field research of this thesis. In order to have more similar archetype and formulation of firm strategies, footwear only retail sector is excluded from the target population as footwear sector has epigenetic characteristics.

The research is conducted by user questionnaires. A total of 46 respondent questionnaires are collected (out of 54 companies). Several methods have been utilized in the data collection process, such as conducting the questionnaire by mail, electronic mail (accompanied by a cover letter) and phone calls. 46 of the questionnaires obtained included in the analysis. 5 point Likert scale " $1=$ Strongly Disagree" to " $5=$ Strongly Agree" was employed to measure all the items in the first part of the questionnaire. The survey statements; between 1 and 12 are related with basic facts and demographic information, between 13 and 55 are related with the hypotheses, 56 and 57 are open-ended questions, which will be contributing to the related hypothesis at the end of the study. 
Regarding the literature review, following model (Figure 2) was designed and was proposed to be used in the study. Depending on the research model proposed, six hypotheses were formulated:

Figure 2: Proposed Research Model

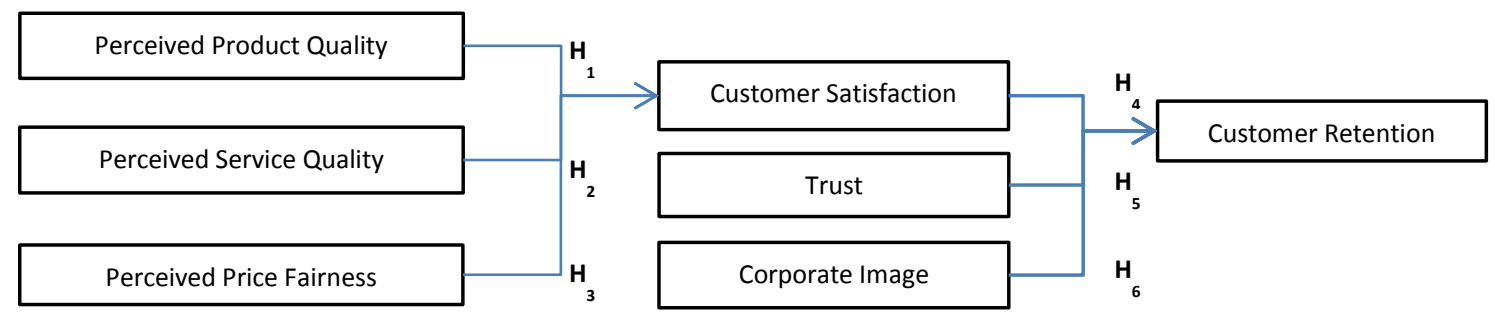

The hypotheses can be summarized as follows (question links are given at Figure 3-8):

$\mathbf{H}_{1}$ : There is a significant and positive effect of perceived product quality on customer satisfaction.

$\mathrm{H}_{2}$ : There is a significant and positive effect of perceived service quality on customer satisfaction.

$\mathbf{H}_{3}$ : There is a significant and positive effect of perceived price fairness on customer satisfaction.

$\mathbf{H}_{4}$ : There is a significant and positive effect of customer satisfaction on customer retention.

$\mathbf{H}_{5}$ : There is a significant and positive effect of trust on customer retention.

$\mathbf{H}_{6}$ : There is a significant and positive effect of corporate image on customer retention.

The details about the items (questions) used in the questionnaire to measure the related variables are summarized in the following figures. The survey question 18 (SQ18 = We believe that, we have a high level of customer satisfaction), measures the customer satisfaction level from the perspective of the managers.

Survey questions for each hypothesis is given in the below figures (Figure 3-8).

Figure 3: The Questions Designed for Measuring $\mathrm{H}_{1}$

S.Q.: Survey Question

\begin{tabular}{|c|c|c|}
\hline $\begin{array}{l}\text { S.Q.13: Providing detailed } \\
\text { information, sufficient } \\
\text { introduction, user opinions etc. } \\
\text { about the products is important in } \\
\text { terms of customer satisfaction. }\end{array}$ & $\begin{array}{l}\text { S.Q.15: Offering a wide range of } \\
\text { products, ensuring that you find } \\
\text { what you need, without having to } \\
\text { browse another site is crucial to } \\
\text { customer satisfaction. }\end{array}$ & $\begin{array}{l}\text { S.Q.16: Offering as many product } \\
\text { types as possible in the on-line } \\
\text { (internet) channel is important for } \\
\text { customer satisfaction. }\end{array}$ \\
\hline $\begin{array}{l}\text { S.Q.14: The accuracy and quality of } \\
\text { the information given about the } \\
\text { product is important for customer } \\
\text { satisfaction. }\end{array}$ & $\begin{array}{l}\text { H1: There is a significant and } \\
\text { positive effect of perceived } \\
\text { product quality on customer }\end{array}$ & $\begin{array}{l}\text { S.Q. 17: Offering as many product } \\
\text { types as possible in the off-line } \\
\text { (store) channel is important for } \\
\text { customer satisfaction. }\end{array}$ \\
\hline
\end{tabular}

Survey questions designed for measuring $\mathrm{H}_{1}$ are detailing accuracy and detail of the product information, assortment variety and types of the offered products in summary. 
Figure 4: The Questions Designed for Measuring $\mathrm{H}_{2}$

\begin{tabular}{|c|c|c|}
\hline S.Q.: Survey Question & \multirow{3}{*}{$\begin{array}{l}\text { S.Q.22: The availability of } \\
\text { different channels such as on- } \\
\text { line (internet) service and e- } \\
\text { mail other than tele-support } \\
\text { as a service affects customer } \\
\text { satisfaction positively. }\end{array}$} & \multirow{2}{*}{$\begin{array}{l}\text { S.Q.23: Sharing information about } \\
\text { product or service experience via on- } \\
\text { line (internet) communities or club is } \\
\text { important for customer satisfaction. }\end{array}$} \\
\hline $\begin{array}{l}\text { S.Q.19: Having the on-line (internet) } \\
\text { store always working condition and } \\
\text { proper functioning of all functions is }\end{array}$ & & \\
\hline important for customer satisfaction. & & \\
\hline $\begin{array}{l}\text { S.Q.20: Continuous updating of the on- } \\
\text { line (internet) store is important for } \\
\text { customer satisfaction. }\end{array}$ & satisfaction positively. & $\begin{array}{l}\text { policy, the guarantee terms and how to } \\
\text { get the money back is important for } \\
\text { customer satisfaction. }\end{array}$ \\
\hline $\begin{array}{l}\text { S.Q.21: It is important for customer } \\
\text { satisfaction to have customer service } \\
\text { and support from the beginning to the } \\
\text { end of the buying period. }\end{array}$ & $\sqrt{\gamma}$ & $\begin{array}{l}\text { S.Q. 25: Offering suggestions according } \\
\text { to customers' shopping preferences at } \\
\text { the on-line (internet) store is important } \\
\text { for customer satisfaction. }\end{array}$ \\
\hline $\begin{array}{l}\text { S.Q. 28: On-line (internet) service quality } \\
\text { level is an important determinant of } \\
\text { customer satisfaction. }\end{array}$ & $\begin{array}{l}\text { S.Q. 27: Off-line (store) } \\
\text { service quality level is an } \\
\text { important determinant of } \\
\text { customer satisfaction. }\end{array}$ & $\begin{array}{l}\text { S.Q. 26: Offering suggestions based on } \\
\text { customer's on-line navigation history is } \\
\text { important for customer satisfaction. }\end{array}$ \\
\hline
\end{tabular}

Survey questions designed for measuring $\mathrm{H}_{2}$ are detailing full functionality and updating of websites, service support, service quality, online experience sharing, offering suggestions to the consumer.

\section{Figure 5: The Questions Designed for Measuring $\mathrm{H}_{3}$}

S.Q.: Survey Question

S.Q.29: When the product price is explained with its advantages, and comparison opportunity is given, it offers an advantage in terms of customer satisfaction.

S.Q.30: Sending special discount invitations to you customers is imnortant for customer satisfaction.

S.Q.31: Keeping history of the products that customers are interested in and proposing discounts at the on-line channel is important in terms of customer satisfaction.

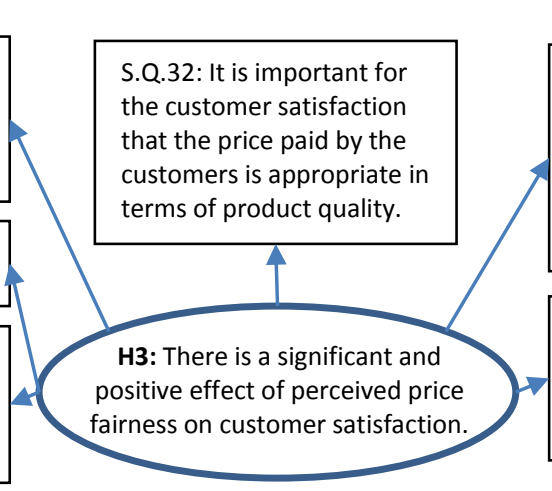

S.Q.33: It is important for customer satisfaction that the price of products on the on-line (internet) and off-line (store) sales channels are always the same.

\section{S.Q. 34: Better price on on-} line (internet) channel is important for customer satisfaction.

Survey questions designed for measuring $\mathrm{H}_{3}$ are detailing prices, discount invitations, pricing policies according to the channel on customer satisfaction.

\section{Figure 6: The Questions Designed for Measuring $\mathrm{H}_{4}$}

\begin{tabular}{|l|l|l|l|}
\hline $\begin{array}{l}\text { S.Q.: Survey Question } \\
\text { successful complaints management } \\
\text { process contribute to customer retention } \\
\text { by increasing customer satisfaction. }\end{array}$ & $\begin{array}{l}\text { S.Q.37: Employees' willingness to } \\
\text { listen to customers' needs has a } \\
\text { positive impact on customer } \\
\text { retention. }\end{array}$ \\
\hline $\begin{array}{l}\text { S.Q.36: Being able to produce effective } \\
\text { solutions to customer complaints } \\
\text { contributes to our ability to retain } \\
\text { customers. }\end{array}$ & $\begin{array}{l}\text { S. If any, a price advantage } \\
\text { explained with its reasons offered } \\
\text { in the on-line (internet) channel } \\
\text { has a positive effect on customer } \\
\text { retention. }\end{array}$ \\
\hline
\end{tabular}

Survey questions designed for measuring $\mathrm{H}_{4}$ are detailing service support, complaints management, listening to the customers, price differentiation policies between on-line and off-line channels and inventory level policies on retention. 
Figure 7: The Questions Designed for Measuring $\mathrm{H}_{5}$

\begin{tabular}{|c|c|c|}
\hline $\begin{array}{l}\text { S.Q.40: On-line (internet) information } \\
\text { security, such as credit card information, } \\
\text { personal information and purchase } \\
\text { records, has a positive impact on } \\
\text { customer trust. }\end{array}$ & $\begin{array}{l}\text { S.Q.43: In the case of on-line } \\
\text { (internet) orders, the trust that } \\
\text { the customer's product will be } \\
\text { shipped is important for the } \\
\text { retention of customers. }\end{array}$ & $\begin{array}{l}\text { S.Q.44: It is important to be } \\
\text { honest with customers and } \\
\text { provide accurate information on } \\
\text { time. }\end{array}$ \\
\hline $\begin{array}{l}\text { S.Q.41: Customer confidence in our } \\
\text { ability to fulfill our commitments has a } \\
\text { positive effect on our ability to retain }\end{array}$ & & $\begin{array}{l}\text { S.Q.45: Customer trust in the } \\
\text { ability of employees to offer } \\
\text { products and services is important } \\
\text { in terms of customer retention. }\end{array}$ \\
\hline & $\downarrow$ & \multirow{2}{*}{$\begin{array}{l}\text { S.Q.46: Customer confidence that } \\
\text { employees are knowledgeable } \\
\text { and competent at what they do is } \\
\text { important for retaining } \\
\text { customers. }\end{array}$} \\
\hline $\begin{array}{l}\text { S.Q.42: The customer's trust that the } \\
\text { product will be delivered at the stated } \\
\text { delivery time will have a positive effect } \\
\text { on the customer retention. }\end{array}$ & $\begin{array}{l}\text { S.Q.47: Customers' trust in the } \\
\text { brand contributes positively to } \\
\text { their retention. }\end{array}$ & \\
\hline
\end{tabular}

Survey questions designed for measuring $\mathrm{H}_{5}$ are detailing on-line security, customer trust in various perspectives from to the brand, delivery, to ability to perform, and honesty to the customer and trying to highlight their effects on customer retention.

Figure 8: The Questions Designed for Measuring $\mathrm{H}_{6}$

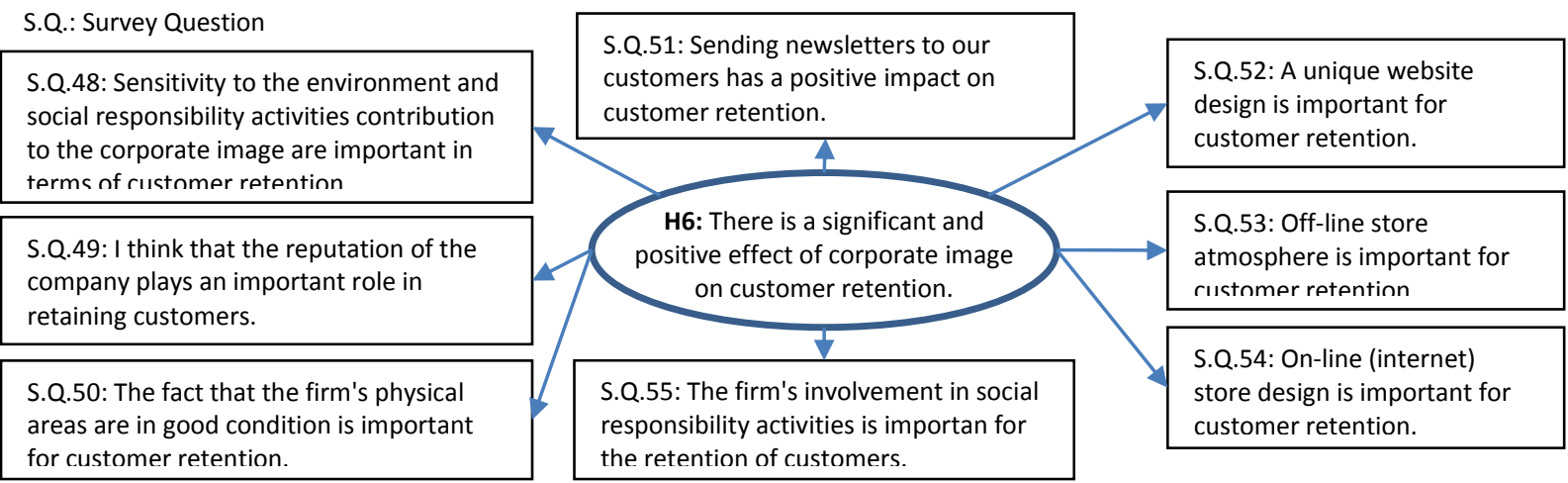

Survey questions designed for measuring $\mathrm{H}_{6}$ are detailing environmental sensitivity, reputation, effects of physical condition/design and atmosphere, effect of newsletters, social responsibility, and website design on customer retention.

Several analyses have been performed in this study. Despite frequency analysis, factor analysis has been conducted to reveal the dimensionality of the variables in the research model. In other words, the aim of the factor analysis was to find out whether the variables are unidimensional or not. In this regard, principle component analysis using Varimax rotation was performed and the reliabilities of the scales have been assessed by alpha coefficient.

Depending on the results of the factor analysis, correlation and regression analyses have been used to test the hypotheses of the study. There are seven variables in the research model. Since six of them has more than one question, factor analysis was performed for all of these six variables that are perceived product quality, perceived service quality, perceived price fairness, trust, customer retention and corporate image. Among the seven variables in the research model, only customer satisfaction was measured by one question (Q18 = We think that, we have a high customer satisfaction level), which means that there is no need to assess the unidimensionality of this variable. The results of the factor analysis are summarized as follows:

Factor Analysis for Perceived Product Quality: To reveal the dimensions of material values scale exploratory factor analysis with Principle component factoring and Varimax rotation was conducted. In order to test the appropriateness of the data for factor analysis Kaiser-Meyer-Olkin measure of sampling adequacy and Bartlett test of sphericity tests were employed. In the initial analysis the scores were adequate to conduct factor analysis. 
Next, the diagonals of the anti-image correlation matrix were examined and it is concluded that other than question 13 (anti image correlation value $=0.498$ ) all the values are higher than 0.50 supporting the idea that these items of the scale are appropriate for the factor analysis. This outcome required the exclusion of question 13. After this step, the factor analysis was conducted again on four items of the perceived product quality scale.

The results of the test mentioned were satisfactory pointing out that data is adequate for conducting factor analysis $(\mathrm{KMO}=0.616$; Bartlett Test: Approx.Chi-Square= 36.583; $\mathrm{df}=6$; $\mathrm{Sig}=0.000)$. In fact, KMO levels between $0.60-0.70$ signals moderate levels of appropriateness but considering the low sample size this values can be regarded as acceptable and well enough for this study (Durmuş, Yurtkoru and Çinko, 2011, p.80).

In this second factor analysis, the diagonals of the anti-image correlation matrix were examined again and it is concluded that all the values are higher than 0.50 supporting the idea that each item of the scale is appropriate for the factor analysis. Factors with eigenvalues over one were retained while the items with factor loadings below 0.50 were discarded (Hair, Anderson, Tahtam and Black, 1998).

The results of the factor analysis for perceived product quality point out the unidimensional structure of the variable. In other words, there is only one factor explaining the $51.579 \%$ of the total variance (KMO $=0.616$; Bartlett Test: Approx.ChiSquare $=36.583 ; \mathrm{df}=6 ; \mathrm{Sig}=0.000$ ). The items under this variable and the reliability values (Cronbach's Alpha Values) are explained in the table below. As can be seen from Table 1, Cronbach's alpha level of the factor is acceptable since it is higher than 0.70 (Nunnally, 1979).

Table 1: Results of the Factor Analysis for Perceived Product Quality

Factor-1: Perceived Product Quality

Q14: The accuracy and quality of the information given about the product is important for customer satisfaction

Q15: Offering a wide range of products, ensuring that you find what you need, without having to browse another site is crucial to customer satisfaction.

Q16: Offering as many product types as possible in the on-line (internet) channel is important for customer satisfaction.

Q17: Offering as many product types as possible in the off-line (store) channel is important for customer satisfaction.

(Total Variance Explained $=51.579 \%$, Eigenvalues=2.063; Cronbach's Alpha=0.712)

Note: Since only one factor was extracted factor loadings cannot be displayed.

Factor Analysis for Perceived Service Quality: The same steps were followed for the factor analysis of perceived service quality. In the initial analysis the anti-image correlation value of Q20 (question 20) was lower than 0.50. Due to this factor Q20 was discarded and the factor analysis was repeated.

The second factor analysis results showed that the data are available for conducting factor analysis (KMO $=0.826$; Bartlett test $=$ Approx. Chi-Square=227.197; $d o=36 \mathrm{Sig}=0.000$ ). Factor loadings and the results of the reliability analysis were all satisfactory including values within the acceptable range. As a result no items were eliminated in the factor analysis and two factors were obtained. The total variance explained was approximately $67 \%$. The results of the exploratory factor analysis for perceived service quality are summarized in Table $2(\mathrm{KMO}=.826$; Bartlett test $=$ Approx.Chi-Square $=227.197$; $\mathrm{df}=36 \mathrm{Sig}=0.000$ ). 
Table 2: Results of the Factor Analysis for Perceived Service Quality

\begin{tabular}{|c|c|c|c|c|}
\hline & \\
\hline & $\begin{array}{l}\text { Factor } \\
\text { Loading }\end{array}$ & $\begin{array}{c}\text { \% of } \\
\text { Variance }\end{array}$ & Eigenvalues & $\begin{array}{c}\text { Cronbach's } \\
\text { Alpha }\end{array}$ \\
\hline Factor-1: Service Support and Complaint Handling & & 34.817 & 4.837 & 0.846 \\
\hline $\begin{array}{l}\text { Q21: It is important for customer satisfaction to have customer service and } \\
\text { support from the beginning to the end of the buying period. }\end{array}$ & 0.902 & & & \\
\hline $\begin{array}{l}\text { Q24: Clearly specifying the return policy, the guarantee terms and how to get } \\
\text { the money back is important for customer satisfaction. }\end{array}$ & 0.784 & & & \\
\hline $\begin{array}{l}\text { Q28: On-line (internet) service quality level is an important determinant of } \\
\text { customer satisfaction. }\end{array}$ & 0.736 & & & \\
\hline $\begin{array}{l}\text { Q22: The availability of different channels such as on-line (internet) service } \\
\text { and e-mail other than tele-support as a service affects customer satisfaction } \\
\text { positively.. }\end{array}$ & 0.628 & & & \\
\hline $\begin{array}{l}\text { Q27: Off-line (store) service quality level is an important determinant of } \\
\text { customer satisfaction. }\end{array}$ & 0.530 & & & \\
\hline Factor-2: Customer Experience and Suggestions Provided & & 32.289 & 1.203 & 0.813 \\
\hline $\begin{array}{l}\text { Q26: Offering suggestions based on customer's on-line navigation history is } \\
\text { important for customer satisfaction. }\end{array}$ & 0.887 & & & \\
\hline $\begin{array}{l}\text { Q25: Offering suggestions according to customers' shopping preferences at } \\
\text { the on-line (internet) store is important for customer satisfaction. }\end{array}$ & 0.872 & & & \\
\hline $\begin{array}{l}\text { Q19: Having the on-line (internet) store always working condition and proper } \\
\text { functioning of all functions is important for customer satisfaction. }\end{array}$ & 0.596 & & & \\
\hline $\begin{array}{l}\text { Q23: Sharing information about product or service experience via on-line } \\
\text { (internet) communities or club is important for customer satisfaction. }\end{array}$ & 0.588 & & & \\
\hline
\end{tabular}

(KMO=.826; Bartlett test = Approx. Chi-Square=227.197; $\mathrm{df}=36 \mathrm{Sig}=0.000)$

Factor Analysis for Perceived Price Fairness: Due to low factor loadings and anti-image correlation values Q33 and Q34 were excluded from the analysis depending on the results of the initial factor analysis. After the elimination of these items, the factor analysis was repeated. Based on the final factor analysis results the KMO and Bartlett test values are satisfactory $(\mathrm{KMO}=0.649 ;$ Bartlett test $=$ Approx.Chi-Square $=33.724 ; \mathrm{df}=6 \mathrm{Sig}=0.000)$. Also results revealed that this variable is unidimensional. In other words, there is only one factor explaining the $52.724 \%$ of the total variance. The Cronbach's Alpha value of this factor is also acceptable $(\alpha=0.699)$. Other values are: Total Variance Explained $=52.724 \%$, Eigenvalues $=2.109$, Cronbach's Alpha=0.699.

Table 3: Results of the Factor Analysis for Perceived Price Fairness

\section{Factor-1: Perceived Price Fairness}

Q29: When the product price is explained with its advantages, and the comparison opportunity is given, it offers an advantage in terms of customer satisfaction.

Q30: Sending special discount invitations to your customers is important for customer satisfaction.

Q31: Keeping history of the products that customers are interested in and proposing discounts at the on-line channel is important in terms of customer satisfaction.

Q32: It is important for the customer satisfaction that the price paid by the customers is appropriate in terms of product quality.

(Total Variance Explained=52.724\%, Eigenvalues=2.109, Cronbach's Alpha=0.699)

Factor Analysis for Customer Retention: The results of the factor analysis for customer retention point out the unidimensional structure of the variable. In other words, there is only one factor explaining the $59.543 \%$ of the total variance $(\mathrm{KMO}=.793$; Bartlett test $=$ Approx. Chi-Square=92.379; $\mathrm{df}=10 ; \mathrm{Sig}=0.000)$. All the values for $\mathrm{KMO}$ and Bartlett test are above the acceptable levels.

When the Cronbach's Alpha value of the factor was examined, it is noted that this value is 0.793 . But as can be seen from Table 4, deletion of Q38 increases the Cronbach Alpha level by approximately 7\%. Depending on the results of the reliability analysis Question 38 is discarded and the factor analysis is repeated. 
Table 4: Cronbach's Alpha Values If Items Are Deleted

\begin{tabular}{|c|r|r|r|r|}
\hline $\begin{array}{c}\text { Survey } \\
\text { Qustion }\end{array}$ & $\begin{array}{c}\text { Scale Mean if } \\
\text { Item Deleted }\end{array}$ & $\begin{array}{c}\text { Scale Variance if } \\
\text { Item Deleted }\end{array}$ & $\begin{array}{c}\text { Corrected Item- } \\
\text { Total Correlation }\end{array}$ & $\begin{array}{c}\text { Cronbach's Alpha } \\
\text { if Item Deleted }\end{array}$ \\
\hline Q35 & 16.20 & 6.161 & 0.748 & 0.699 \\
Q36 & 16.22 & 6.618 & 0.727 & 0.715 \\
Q37 & 16.48 & 6.211 & 0.666 & 0.723 \\
Q38 & $\mathbf{1 7 . 0 4}$ & $\mathbf{7 . 1 5 4}$ & $\mathbf{0 . 2 9 1}$ & $\mathbf{0 . 8 6 2}$ \\
Q39 & 16.50 & 6.833 & 0.561 & 0.758 \\
\hline
\end{tabular}

The results of the final factor analysis are similar with the first one pointing out the unidimensional structure of the variable. But it is noted that this time, the factor obtained explained the $71.326 \%$ of the total variance. All the values for $\mathrm{KMO}$ and Bartlett test are above the acceptable level again $(\mathrm{KMO}=.779 ;$ Bartlett test $=$ Approx.Chi-Square $=88.857 ; \mathrm{df}=6$, Sig=0.000). As expected the deletion of Q38 increased the Cronbach Alpha level to 0862. Values of factor analysis are: Total Variance Explained $=71.326 \%$, Eigenvalues $=2.853$; Cronbach's Alpha $=0.862$. The statements under the customer retention factor are summarized in Table 5.

Table 5: Results of the Factor Analysis for Customer Retention

\begin{tabular}{|l|}
\hline Factor-1: Customer Retention \\
\hline $\begin{array}{l}\text { Q35: Customer service support and a successful complaints management process contribute to customer retention by increasing } \\
\text { customer satisfaction. }\end{array}$ \\
\hline Q36: Being able to produce effective solutions to customer complaints contributes to our ability to retain customers. \\
\hline Q37: Employees' willingness to listen to customers' needs has a positive impact on customer retention. \\
\hline Q39: Online (internet) satışa sunulan ürünlerin stokta olması müşterilerin elde tutulmasına olumlu katkı sağlar. \\
\hline Total Variance Explained=71.326\%, Eigenvalues $=2.853 ;$ Cronbach's Alpha=0.862
\end{tabular}

Factor Analysis for Trust: The same steps were followed for the factor analysis of trust. Results of the tests conducted showed that the data are available for conducting factor analysis $(K M O=.758$; Bartlett test $=$ Approx.Chi-Square $=215.200$; $\mathrm{df}=28, \mathrm{Sig}=0.000$ ). The results of the factor analysis pointed out that there are two factors explaining the $71.345 \%$ of the total variance. The reliability values of the factors are within the acceptable range. The results of the exploratory factor analysis for trust are summarized in the table below.

Table 6: Results of the Factor Analysis for Trust

\begin{tabular}{|c|c|c|c|c|}
\hline & $\begin{array}{l}\text { Factor } \\
\text { Loading }\end{array}$ & $\begin{array}{c}\% \text { of } \\
\text { Variance }\end{array}$ & Eigenvalues & $\begin{array}{c}\text { Cronbach's } \\
\text { Alpha }\end{array}$ \\
\hline Factor-1: Trust Towards The Services Provided & & 39.133 & 4.322 & 0.880 \\
\hline $\begin{array}{l}\text { Q43: In the case of on-line (internet) orders, the trust that the customer's } \\
\text { product will be shipped is important for the retention of customers. }\end{array}$ & 0.876 & & & \\
\hline $\begin{array}{l}\text { Q42: The customer's turst that the product will be delivered at the stated } \\
\text { delivery time will have a positive effect on the customers retention. }\end{array}$ & 0.831 & & & \\
\hline $\begin{array}{l}\text { Q41: Customer confidence in our ability to fulfill our commitments has a } \\
\text { positive effect on our ability to retain customers. }\end{array}$ & 0.812 & & & \\
\hline $\begin{array}{l}\text { Q44: It is important to be honest with customers and provide accurate } \\
\text { information on time. }\end{array}$ & 0.807 & & & \\
\hline Factor-2: Trust Towards The Company and Brand & & 32.212 & 1.386 & 0.810 \\
\hline $\begin{array}{l}\text { Q46: Customer confidence that employees are knowledgeable and competent } \\
\text { at what they do is important for retaining customers. }\end{array}$ & 0.925 & & & \\
\hline $\begin{array}{l}\text { Q45: Customer trust in the ability of employees to offer products and services } \\
\text { is important in terms of customer retention. }\end{array}$ & 0.869 & & & \\
\hline Q47: Customers' trust in the brand contributes positively to their retention. & 0.650 & & & \\
\hline $\begin{array}{l}\text { Q40: On-line (internet) information security, such as credit card information, } \\
\text { personal inf. and purchase records, has a positive impact on customer trust. }\end{array}$ & 0.534 & & & \\
\hline
\end{tabular}

$(\mathrm{KMO}=.758 ;$ Bartlett test $=$ Approx. Chi-Square $=215.200 ; \mathrm{df}=28, \mathrm{Sig}=0.000)$ 
Factor Analysis for Corporate Image: The initial factor analysis performed required the deletion of Q50 due to low factor loading (0.402). After discarding this item the factor analysis was performed again. The results of the second factor analysis showed that the data are appropriate for conducting factor analysis with values of $(\mathrm{KMO}=0.633$; Bartlett test $=$ Approx. ChiSquare=109.352; $\mathrm{df}=21, \mathrm{Sig}=0.000$ ). Depending on the results of the factor analysis it is concluded that there are two factors with eigenvalues greater than one, explaining the $62.536 \%$ of the total variance. When the Cronbach's Alpha values are examined it is revealed that the deletion of Q51 in the second factor increases the Cronbach's Alpha value by approximately $12 \%$. Thus, Q51 is discarded and the factor analysis was repeated for the third time.

The results of the last factor analysis showed that the data are appropriate for conducting factor analysis with values of $(\mathrm{KMO}=.613$; Bartlett test $=$ Approx.. Chi-Square=96.633; $\mathrm{df}=15, \mathrm{Sig}=0.000)$. Depending on the results of the factor analysis it is concluded that there are two factors with Eigenvalues greater than one, explaining the $68.712 \%$ of the total variance. The Cronbach's Alpha values of the factors are also acceptable. The results of the factor analysis conducted for corporate image is summarized in the following table (Table 7).

Table 7: Results of the Factor Analysis for Corporate Image

\begin{tabular}{|c|c|c|c|c|}
\hline & $\begin{array}{l}\text { Factor } \\
\text { Loading }\end{array}$ & $\begin{array}{c}\% \text { of } \\
\text { Variance }\end{array}$ & Eigenvalues & $\begin{array}{l}\text { Cronbach's } \\
\text { Alpha }\end{array}$ \\
\hline Factor-1: Corporate Reputation & & 38.559 & 2.774 & 0.750 \\
\hline Q54: On-line (internet) store design is important for customer retention. & 0.829 & & & \\
\hline Q52: A unique website design is important for customer retention. & 0.768 & & & \\
\hline Q53: Off-line store atmosphere is important for customer retention. & 0.730 & & & \\
\hline $\begin{array}{l}\text { Q49: I think that the reputation of the company plays an important role in } \\
\text { retaining customers. }\end{array}$ & 0.655 & & & \\
\hline Factor-2: Corporate Social Responsibility & & 30.153 & 1.348 & 0.859 \\
\hline $\begin{array}{l}\text { Q55: The firm's involvement in social responsibility activities is importan for the } \\
\text { retention of customers. }\end{array}$ & 0.940 & & & \\
\hline $\begin{array}{l}\text { Q48: Sensitivity to the environment and social responsibility activities } \\
\text { contribution to the corporate image are important in terms of customer } \\
\text { retention. }\end{array}$ & 0.900 & & & \\
\hline
\end{tabular}

$(\mathrm{KMO}=.613 ;$ Bartlett test $=$ Approx. Chi-Square $=96.633 ; \mathrm{df}=15, \mathrm{Sig}=0.000)$.

Research Model and Hypotheses after the Factor Analysis: Since three of the variables in the model have more than one dimension, there is a need to adjust the research model considering these dimensions of the factors. In other words, depending on the results of the factor analysis research model and the hypotheses are reformulated. The following figure (Figure 9) summarizes the research model after factor analysis results.

Figure 9: Adjusted Research Model after Factor Analysis

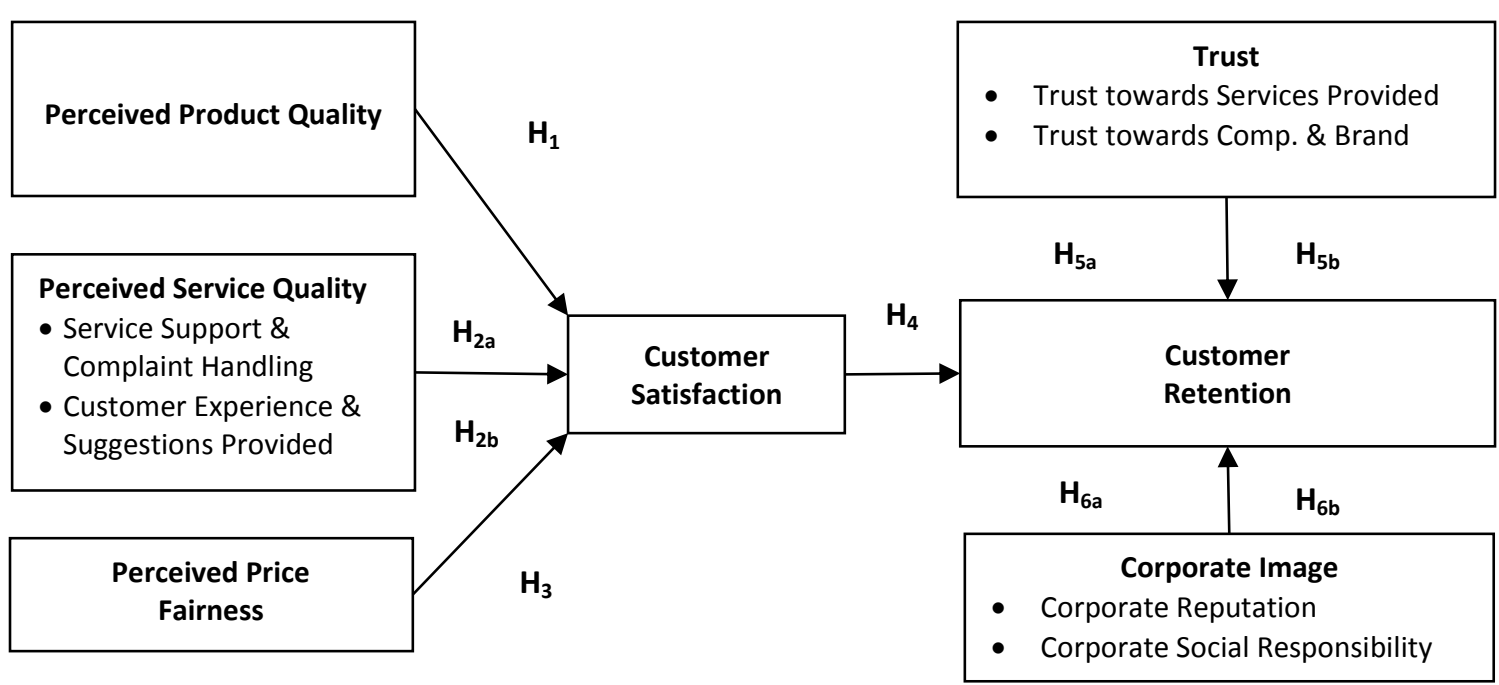


$\mathbf{H}_{1}$ : There is a significant and positive effect of perceived product quality on customer satisfaction.

$\mathbf{H}_{\mathbf{2}}$ : There is a significant and positive effect of a) service support and complaint handling and b) customer experience and suggestions provided on customer satisfaction.

$\mathbf{H}_{3}$ : There is a significant and positive effect of perceived price fairness on customer satisfaction.

$\mathbf{H}_{4}$ : There is a significant and positive effect of customer satisfaction on customer retention.

$\mathbf{H}_{5}$ : There is a significant and positive effect of a) trust towards services provided and $\mathbf{b}$ ) trust toward company and brand on customer retention.

$\mathbf{H}_{6}$ : There is a significant and positive effect of a) corporate reputation and $\mathbf{b}$ ) corporate social responsibility on customer retention.

So, depending on the results of the factor analysis nine hypotheses are provided in total. In total, six of these are formulated as sub hypotheses of $\mathrm{H}_{2}, \mathrm{H}_{5}$ and $\mathrm{H}_{6}$.

Results of the Correlation and Regression Analyses: In order to test the hypotheses of the study multiple regression analysis is conducted. The first multiple regression analysis was conducted to reveal the effects of perceived product quality, service support and complaint handling, customer experience and suggestions provided and perceived price fairness on customer satisfaction. Since there are several independent variables and only one dependent variable (customer satisfaction) multiple regression analysis was employed.

The other multiple regression analysis was conducted to examine the effects of customer satisfaction, corporate reputation, corporate social responsibility, trust towards services provided and trust towards company and brand on customer retention. But before the multiple regression analysis a correlation analysis was performed to reveal the correlations between the independent variables. The results of the Pearson correlation analysis are summarized below:

As can be seen from Table 8, perceived product quality, service support and complaint handling, customer experience and suggestions provided and perceived price fairness have statistically significant correlations between customer satisfaction (Sig values ( $p$ values) respectively are $=0.001 ; 0.000 ; 0.000$ and 0.000 ). The correlation levels of customer satisfaction with; (1) Perceived product quality is $46.6 \%$, (2) Service support and complaint handling is $65.8 \%$, (3) Customer experience and suggestions provided is 55.1, (4) Perceived price fairness is $52.4 \%$.

Table 8: The Results of the Pearson Correlation Analysis -1

\begin{tabular}{|c|c|c|c|c|c|c|}
\hline \multicolumn{7}{|c|}{ Correlations } \\
\hline & & $\begin{array}{l}\text { CustomerSati } \\
\text { sfaction }\end{array}$ & $\begin{array}{l}\text { PerceivedQua } \\
\text { lity }\end{array}$ & $\begin{array}{l}\text { ServiceSuppo } \\
\text { ttComplaint }\end{array}$ & $\begin{array}{l}\text { CustomerExp } \\
\text { erienceandSu } \\
\text { ggestions }\end{array}$ & $\begin{array}{c}\text { PerceivedPric } \\
\text { eFairness }\end{array}$ \\
\hline \multirow[t]{3}{*}{ CustomerSatisfaction } & Pearson Correlation & 1 & $.466^{2 x}$ & $.658^{1 x}$ & $.551^{\mathrm{n}}$ & $.524^{\mathrm{n}}$ \\
\hline & Sig. (2-tailed) & &, 001 &, 000 &, 000 &, 000 \\
\hline & $\mathrm{N}$ & 46 & 46 & 46 & 46 & 46 \\
\hline \multirow[t]{3}{*}{ PerceivedQuality } & Pearson Correlation & $.466^{1 \times}$ & 1 & $.407^{\mathrm{nt}}$ & $347^{*}$ & $302^{*}$ \\
\hline & Sig. (2-tailed) &, 001 & & ,005 & ,018 &, 042 \\
\hline & $\mathrm{N}$ & 46 & 46 & 46 & 46 & 46 \\
\hline \multirow[t]{3}{*}{ ServiceSupportComplaint } & Pearson Correlation &, $658^{\mathrm{kn}}$ & $407^{n \times}$ & 1 & $.668^{12}$ & $.632^{\text {nn }}$ \\
\hline & Sig. (2-tailed) &, 000 & ,005 & & , 000 &, 000 \\
\hline & N & 46 & 46 & 46 & 46 & 46 \\
\hline \multirow{3}{*}{$\begin{array}{l}\text { CustomerExperienceand } \\
\text { Suggestions }\end{array}$} & Pearson Correlation & $.551^{\star \pi}$ & $347^{*}$ & $.668^{\pi x}$ & 1 & $.611^{\pi x}$ \\
\hline & Sig. (2-tailed) &, 000 & 018 &, 000 & &, 000 \\
\hline & $\mathrm{N}$ & 46 & 46 & 46 & 46 & 46 \\
\hline \multirow[t]{3}{*}{ PerceivedPriceFairness } & Pearson Correlation & $524^{\prime \pi}$ &, $302^{x}$ &, $632^{\text {nk }}$ & $.611^{n+}$ & 1 \\
\hline & Sig. (2-tailed) &, 000 &, 042 & , 000 & , 000 & \\
\hline & $\mathrm{N}$ & 46 & 46 & 46 & 46 & 46 \\
\hline
\end{tabular}

**. Correlation is significant at the 0.01 level (2-tailed).

*. Correlation is significant at the 0.05 level (2-tailed). 
The next correlation analysis was performed to reveal the correlations between customer retention, customer satisfaction, trust towards service provided, trust towards company and brand, corporate reputation and corporate social responsibility. The results of the Pearson correlation analysis can be seen from Table 9.

As can be seen from Table 9 customer satisfaction, trust towards service, trust towards company and brand, corporate reputation and corporate social responsibility have statistically significant correlations between customer retention (Sig values ( $p$ values) respectively are $=0.000 ; 0.000 ; 0.000$ and 0.048 ). The correlation levels of customer retention with; (1) Customer satisfaction is $53.6 \%$, (2) Trust towards service is $71.6 \%$, (3) Trust towards company and brand is $82.3 \%$, (4) Corporate reputation is $65.5 \%$, (5) Corporate social responsibility is $29.3 \%$.

Table 8 and Table 9 point out that although there are correlations between independent variables; there is no multicollinearity since all the correlation levels are below 0.70 (Hair, et.al, 1998, p.193).

Table 9: The Results of the Pearson Correlation Analysis - 2

\begin{tabular}{|c|c|c|c|c|c|c|c|}
\hline \multicolumn{8}{|c|}{ Correlations } \\
\hline & & $\begin{array}{l}\text { CustomerSati } \\
\text { sfaction }\end{array}$ & $\begin{array}{c}\text { CustomerRet } \\
\text { ention }\end{array}$ & $\begin{array}{c}\text { TrustTowardS } \\
\text { envice }\end{array}$ & $\begin{array}{c}\text { TrustTowardC } \\
\text { ompanyandBr } \\
\text { and }\end{array}$ & $\begin{array}{c}\text { CorporateRep } \\
\text { utation }\end{array}$ & $\begin{array}{l}\text { CorporateSoc } \\
\text { ialResponsibi } \\
\text { lity }\end{array}$ \\
\hline \multirow[t]{3}{*}{ CustomerSatisfaction } & Pearson Correlation & 1 &, $536^{\mathrm{Nx}}$ &, $397^{\mathrm{xx}}$ & $502^{\mathrm{nx}}$ &, 280 & 137 \\
\hline & Sig. (2-tailed) & &, 000 &, 006 &, 000 &, 060 & ,365 \\
\hline & $\mathrm{N}$ & 46 & 46 & 46 & 46 & 46 & 46 \\
\hline \multirow[t]{3}{*}{ CustomerRetention } & Pearson Correlation & $536^{n \pi}$ & 1 &, $716^{\mathrm{nx}}$ & $823^{1 n}$ &, $655^{n \pi}$ & $293^{\star}$ \\
\hline & Sig. (2-tailed) &, 000 & &, 000 &, 000 &, 000 &, 048 \\
\hline & $\mathrm{N}$ & 46 & 46 & 46 & 46 & 46 & 46 \\
\hline \multirow[t]{3}{*}{ TrustTowardService } & Pearson Correlation & $397^{\star x x}$ &, $716^{\mathrm{xn}}$ & 1 & $532^{n \pi}$ & $.555^{\mathrm{kx}}$ & 169 \\
\hline & Sig. (2-tailed) &, 006 &, 000 & &, 000 &, 000 & 263 \\
\hline & $\mathrm{N}$ & 46 & 46 & 46 & 46 & 46 & 46 \\
\hline \multirow{3}{*}{$\begin{array}{l}\text { TrustTowardCompanyan } \\
\text { dBrand }\end{array}$} & Pearson Correlation & $.502^{n \pi}$ & $823^{\text {nx }}$ & $.532^{\mathrm{n}}$ & 1 & $605^{n \pi}$ & $.460^{n \times}$ \\
\hline & Sig. (2-tailed) &, 000 &, 000 &, 000 & & 000 &, 001 \\
\hline & $N$ & 46 & 46 & 46 & 46 & 46 & 46 \\
\hline \multirow[t]{3}{*}{ CorporateReputation } & Pearson Correlation & 280 &, $655^{2 x}$ &, $555^{\mathrm{Nx}}$ & $605^{x x}$ & 1 &, $333^{\star}$ \\
\hline & Sig. (2-tailed) &, 060 &, 000 &, 000 &, 000 & &, 024 \\
\hline & $N$ & 46 & 46 & 46 & 46 & 46 & 46 \\
\hline \multirow{3}{*}{$\begin{array}{l}\text { CorporateSocialRespons } \\
\text { ibility }\end{array}$} & Pearson Correlation & 137 & $293^{x}$ & 169 & $460^{n \pi}$ & $.333^{x}$ & 1 \\
\hline & Sig. (2-tailed) &, 365 &, 048 & 263 &, 001 &, 024 & \\
\hline & $N$ & 46 & 46 & 46 & 46 & 46 & 46 \\
\hline
\end{tabular}

**. Correlation is significant at the 0.01 level (2-tailed)

*. Correlation is significant at the 0.05 level (2-tailed).

Since multicollinearity is a critical barrier for multiple regression analysis VIF coefficients are also to be analysed while regression analysis is conducted. The results of the multiple regression analyses are summarized in Table 10 and Table 11.

As can be seen from Table 10, all the VIF scores are below 10 indicating that multicollinearity is not a problem (Hair, et.al, 1998:193). So the results of the multiple regression analysis can be interpreted.

The results of the multiple regression analysis point out that perceived product quality, service support and complaint handling, customer experience and suggestions provided, perceived price fairness have statistically significant positive effects on customer satisfaction (The sig values/p values respectively are $=0.049 ; 0.018 ; 0.042$ and 0.001 . They are all below 0.05 which means that the alternative hypotheses are accepted). Thus, it can be concluded that $\mathbf{H}_{1}, \mathbf{H}_{2 a}, \mathbf{H}_{2 b}, \mathbf{H}_{3}$ are accepted as expected. 
Table 10: Results of the Multiple Regression Analysis - 1

\begin{tabular}{|c|c|c|c|c|c|c|}
\hline $\begin{array}{l}\text { Dependent Variable: } \\
\text { Customer Satisfaction }\end{array}$ & $\begin{array}{r}\text { Unstand } \\
\text { Coeffi }\end{array}$ & $\begin{array}{l}\text { ardized } \\
\text { cients }\end{array}$ & $\begin{array}{l}\text { Stand. } \\
\text { Coeff. }\end{array}$ & & & \\
\hline Independent Variables & B & Std. Error & Beta & $\mathbf{t}$ & $\begin{array}{l}\text { Sig. } \\
(p)\end{array}$ & VIF \\
\hline Constant & -.354 & .739 & & -.478 & .635 & \\
\hline Perceived Product Quality & .238 & .132 & .219 & 1.803 & .049 & 1.215 \\
\hline $\begin{array}{l}\text { Service Support \& Complaint } \\
\text { Handling }\end{array}$ & .566 & .229 & .405 & 2.471 & .018 & 2.223 \\
\hline $\begin{array}{l}\text { Customer Experience and } \\
\text { Suggestions Provided }\end{array}$ & .153 & .187 & .129 & .821 & .042 & 2.042 \\
\hline Perceived Price Fairness & .167 & .204 & .123 & .821 & .001 & 1.867 \\
\hline
\end{tabular}

In order to see the power of effects of the independent variables on customer satisfaction the Beta coefficients are examined in Table 10. Among the independent variables, service support and complaint handling has the greatest impact on customer satisfaction ( $\beta$ service support and complaint handling $=0.405$ ). It is followed by perceived product quality, customer experience and suggestions provided and perceived price fairness respectively ( $\beta$ perceived product quality $=0.219$, $\beta$ customer experience and suggestions provided $=0.129$, $\beta$ perceived price fairness $=0.123$ ).

Interpretation of the overall results points out that approximately $50.4 \%$ of the variation of customer satisfaction can be explained by the independent variables listed above (perceived product quality, service support and complaint handling, customer experience and suggestions provided, perceived price fairness). The related values of the regression model are $R=0.710 ; \mathbf{R}^{2}=0.504 ;$ Adjusted $R^{2}=0.456 ; F=10.425 ; p=0.000$.

In order to see the effects of customer satisfaction, trust towards services provided, trust towards company and brand, corporate reputation and corporate social responsibility on customer retention another multiple regression analysis was conducted. The results of this analysis are summarized in Table 11. Since all the VIF scores are below 10 indicating that multicollinearity is not a problem the results of the multiple regression analysis can be interpreted.

Table 11: Results of the Multiple Regression Analysis - 2

\begin{tabular}{|c|c|c|c|c|c|c|c|}
\hline $\begin{array}{l}\text { Dependent Variable: } \\
\text { Customer Retention }\end{array}$ & \multicolumn{2}{|c|}{$\begin{array}{l}\text { Unstandardized } \\
\text { Coefficients }\end{array}$} & \multicolumn{5}{|l|}{$\begin{array}{l}\text { Stand. } \\
\text { Coeff. }\end{array}$} \\
\hline Independent Variables & B & Std. Error & Beta & $\mathbf{t}$ & Sig. & (p) & VIF \\
\hline Constant & .162 & .344 & & .470 & & .641 & \\
\hline Customer Satisfaction & .085 & .067 & .105 & 1.271 & & .011 & 1.409 \\
\hline $\begin{array}{l}\text { Trust Toward Service } \\
\text { Provided }\end{array}$ & .282 & .081 & .314 & 3.486 & & .001 & 1.675 \\
\hline $\begin{array}{l}\text { Trust Toward Company \& } \\
\text { Brand }\end{array}$ & .525 & .101 & .552 & 5.181 & & .000 & 2.348 \\
\hline Corporate Reputation & .131 & .087 & .143 & 1.517 & & .007 & 1.834 \\
\hline $\begin{array}{l}\text { Corporate Social } \\
\text { Responsibility }\end{array}$ & .060 & .063 & .076 & .950 & & .002 & 1.312 \\
\hline
\end{tabular}

$\mathrm{R}=0.898 ; \mathbf{R}^{2}=0.807 ;$ Adjusted $\mathbf{R}^{2}=0.782 ; \mathrm{F}=33.368 ; \mathbf{p}=0.000$

The results of the multiple regression analysis point out that customer satisfaction, trust toward services provided, trust toward company and brand, corporate reputation and corporate social responsibility have statistically significant positive 
effects on customer retention (The sig values/p values respectively are $=0.011 ; 0.001 ; 0.000 ; 0.007$ and 0.002 . They are all below 0.05 which means that the alternative hypotheses are accepted). Thus, it can be concluded that $\mathbf{H}_{4}, \mathbf{H}_{5 a}, \mathbf{H}_{5 b}, \mathbf{H}_{6 a}$ and $\mathbf{H}_{6 \mathrm{~b}}$ are accepted as expected.

In order to see the power of effects of the independent variables on customer retention the Beta coefficients are examined in Table 11. Among the independent variables, trust toward company and brand has the greatest impact on customer retention ( $\beta$ trust toward company and brand $=0.552$ ). It is followed by trust toward services provided, corporate reputation, customer satisfaction and corporate social responsibility respectively ( $\beta$ trust toward services provided $=0.314, \beta$ corporate reputation $=0.143, \beta$ customer satisfaction $=0.105$, $\beta$ corporate social responsibility=0.076).

Interpretation of the overall results points out that $80.7 \%$ of the variation of customer retention can be explained by the independent variables listed above (customer satisfaction, trust toward company and brand, trust toward services provided, corporate reputation, corporate social responsibility). The related values of the regression model are $\mathbf{R}=0.898$; $\mathbf{R}^{2}=0.807 ;$ Adjusted $R^{2}=0.782 ; F=33.368 ; p=0.000$ signalling a very high level of variance explanation.

\section{FINDINGS AND DISCUSSIONS}

The research was conducted among the members of the BMD, the leading association of the retail sector in Turkey, whose members also have a high representation ability of the sector that is under focus. In today's competition based marketspace additionally considedring the fact that customer retention is an undeniable fact, that each company should be improving and giving priority in the formulation of her marketing strategies and action plans.

The outcomes and findings of the study were found to support the objectives of the study and the results of the statistical analysis were found to accept hypotheses of the study. Results indicate that perceived product quality, service support and complaint handling, customer experience and suggestions provided and perceived price fairness have significant and positive effects on customer satisfaction. Furthermore, customer satisfaction, trust towards service provided, trust towards company and brand, corporate reputation and corporate social responsibility have significant and positive effects on customer retention.

The survey question about providing detailed information, sufficient introduction, user opinions and etc. about the products has been eliminated in the initial analysis as a result of factor analysis. On the contrary, accuracy and quality of the information given about the product is perceived to increase customer satisfaction as one of the main product quality obligations. Offering a wide range of products, ensuring that the customer finds what she needs without having to browse another site is emphasized as a perceived product quality centric determinant that have positive effect on customer satisfaction.

Statistical analyses outcomes disclose that marketing executives, not only respect customer retention efforts, but also try to position their customer satisfaction operations to a broader level than just listening to complaints. It is delightfully amusing that marketing mix components are not only considered as futile copy paste marketing activities; on the contrary they are regarded as comprehensive tools to / in reaching customer satisfaction which is suggested to have two vital elements; service support and complaint handling and customer experience and suggestions provided. The factors extracted from the data with high reliability and depicted that executives place great emphasis on service support and complaint handling practices to make a significant difference for consumers. A customer service starting from welcoming stage to after sales is the backbone of the system, supported by a clearly defined return policy, multi-channel customer support mechanism, simultaneously taking care of both off-line and on-line store service quality levels to provide satisfactory customer experience.

The survey questions inquiring the effect of continuous updating of on-line (internet) store has eliminated in initial analysis as a result of factor analysis due to their low anti-image correlation value. It can be considered that this service is seen as a must, lacking it might have negative effects, but doing it will only have companies to keep the pace and does not sustain a perceived remarkable advantage in reality by the respondents.

Further analyses of the responses show that customer experience and suggestions provided at both off-line and online channel are positioned as main pillars of service quality to be sustained by placing emphasis on suggestions provided according to individuals' search and purchase histories. 24/7 full functionality of company websites is also regarded as a customer satisfaction criteria.

It is also depicted that, although experience sharing via online communities and clubs are not seen as significantly important as online search and purchase histories based recommendations, they have also remarkably centered into interest area and have taken part in customer retention strategy formulation of the executives.

Regarding perceived price fairness it is revealed that, marketing professionals value offering customized special discount invitations or discounts for the goods that the customers have shown interest by using their on-line channel surfing history 
is another tool that the executives are using to sustain customer satisfaction. Either having identical prices at off-line and on-line or better prices at on-line channel have been discarded while factor analysis. It can inferred that customers are flexible to accept different prices whether at off-line or on-line channel. Explaining the product's price with its advantages and giving the opportunity of comparison is used to increase customer satisfaction. Additionally the executives emphasize that, customers are more satisfied when they perceive that the price they pay is appropriate for the quality of the product they receive.

Customer service support and a successful complaint handling process are considered as vital by the professionals. Employees' willingness to listen to their customers' needs is seen at utmost importance in a customer service and support system to reach high customer retention rates. On the other hand, keeping on-line (internet) listed products in stock in sufficient amounts is a target carried out by the retailers to reach higher customer retention values.

The research also revealed that trust towards the services provided and trust towards the company and the brand are the main trust related factors extracted that clearly indicate trust's perceived positive effect on customer retention. The trust/confidence that the customer will receive the product at on-line (internet) orders and customer trust that employees are knowledgeable and competent at what they do make a positive impact on customer retention are among the most significant components that has a positive impact on customer retention. Being honest and providing timely accurate information and customers' trust in the brand are perceived critically important.

Regarding corporate image related components of the research model, the factors extracted and the relationships computed bring out two significant factors sustaining customer retention, which are corporate reputation and corporate social responsibility of the firm. The survey questions asking about firm's physical areas' condition and submitting newsletters to customers have been discarded during factor analysis. A firm's social responsibility activities and sensitivity to the environmental issues are the main contributors which are perceived to result in a better corporate image and are important in terms of customer retention. The research findings also highlight that the respondents not only care for their online store design and try to have a customized/unique website, but also give importance to off-line store atmosphere. It is seen that these issues surpass emphasis given on the corporate reputation to sustain customer retention.

\section{CONCLUSION}

The target group is composed of executives who literally direct the sector with their daily applications. Stemming from the respondents' characteristics to have day-to-day interactions about the subject supplies the research a superior feature. "Customer Retention" is an area of research with vital importance; adding the dynamic profile and flexibility of the readyto-wear organized retailers to adapt and deploy global or local new practices into their business model, this research gains a prominent character. Additionally, information and communication technologies (ICT) are transforming data and making it ready to be deployable/reachable to any individual customer, in a way which is generating information almost into a subsymmetric form. These advancements and challenges have the potential to become more remarkable in emerging countries due to intensive investment attractiveness, and will surely affect marketing efforts so that customer retention strategies will be keeping a focal position for academic studies. In managing customer retention efforts Yüksel's (2017, p.282) notes can be taken into account: "The unique qualities imposed by the current way of doing business overwhelm the traditional habits of linear mindset in an age of fluidity. Organizations are far from being capable to grasp the very insight of the emergent phenomena just by dismantling the whole into parts"; so that customer insight would be studied in a complexity thinking mindset to result in insight based actions.

This paper represent originality being the first attempt in Turkey trying to find out decision making criteria and strategy formulation beliefs and practices of top managers of organized retailers with special focus on ready-to-wear textiles sector. The study also facilitates a path for further research based on its theoretical framework. Performed statistical analyses verify that the proposed factors of the adjusted research model significantly contribute to customer retention strategy formulation activities.

The outcomes and findings of the study were found to support the objectives of the study and the results of the statistical analysis were found to accept hypotheses of the study. Results indicate that perceived product quality, service support and complaint handling, customer experience and suggestions provided and perceived price fairness have significant and positive effects on customer satisfaction. Furthermore, customer satisfaction, trust towards service provided, trust towards company and brand, corporate reputation and corporate social responsibility have significant and positive effects on customer retention. Service support and complaint handling (from welcoming to after sales), customer experience and suggestions provided and trust toward company and brand especially play a key role for sustaining customer retention.

This study was conducted in a leading Turkish retail association (BMD) and may not be generalized in other industries. However, by employing these constructs and deploying them even in identical form to other industries, researchers would be able to depict factors that are actively used by industry managers in the same manner and can also produce generic 
results. Cultural differences should be considered when this model is applied in another country. While this study has explored characteristics of the dimensions and differences in the perceived importance among executives, future research may detail the reasons of the differences among other industry segments. This study specifically focuses on organized ready-to-wear retailers; nevertheless as customer retention is vitally important; other sectors or industries may be subject to further research. Potential opportunistic behaviour of the managers should always be kept in mind as they might be depicting a more optimistic picture as per the desired condition of their companies while responding to the survey questions.

The research results also provide tools for both real and virtual markets. On the other hand, application of the same model by targeting customers of the ready-to-wear sector can be an interesting field of study which can be used to reveal what customer do prioritize and/or value. A larger sample of countries from different nations would be appropriate to provide geographical or country level benchmark on the basis of organized ready-to-wear retailers to figure out potential differences in cultural perspectives. Carrying out similar research at other sectors and bringing out sector by sector comparisons can be used as an extensive area of research. In conclusion, this research has drawn attention to the progressive importance of customer retention sustaining efforts in ready-to-wear sector that is under intense competitive pressure.

\section{REFERENCES}

Aflaki, S. and Popescu, I., 2013. Managing Retention in Service Relationships. Faculty \& research Working Paper. [pdf] Insead. Avaliable through: Isik University Library website <http://ezp.isikun.edu.tr:2067/bsi/pdfviewer/pdfviewer?vid=8\&sid=f6c6f6cf-282f-4327-ab18f946a552abe6\%40sessionmgr4010> [Accessed 1 February 2014].

Akbar, M.M., 2013. Three Competing Models on Customer Loyalty in the Context of Mobile Subscribers. International Journal of Marketing Studies, Vol. 5, No. 4, pp.42-58. http://dx.doi.org/10.5539/ijms.v5n4p42

Anderson, J.C. and Narus, J.A. 1998. Business marketing: understand what customers value. [pdf] Harvard Business Review. Available through: Isik University Library website <http://ezp.isikun.edu.tr:2067/bsi/pdfviewer/pdfviewer?vid=10\&sid=f6c6f6cf-282f-4327-ab18f946a552abe6\%40sessionmgr4010> [Accessed 12 July 2014].

Barich, H., P. Kotler., 1991. A Framework for Marketing Image Management, Sloan Management Review, [e-journal] Winter. Avaliable through: Isik University Library website <http://sloanreview.mit.edu/article/a-framework-for-marketing-image-management/> [Accessed 12 March 2013].

Bitner, M.J., 1992. Servicescapes: The Impact of Physical Surroundings on Customers and Employees. Journal of Marketing, [e-journal] 56 (April). Available through: Isik University Library website <http://ezp.isikun.edu.tr:2067/bsi/pdfviewer/pdfviewer?vid=0\&sid=cd19275c3c15-4781-9bf2-\%40sessionmgr4006> [Accessed 10 February 2013].

Brady, M.K., Cronin, Jr.J.J., 2001. Some New Thoughts on Conceptualizing Perceived Service Quality: A Hierarchical Approach. The Journal of Marketing, Vol. 65, No. 3, pp. 34-49. [online] Available at:

<https://www.iei.liu.se/fek/frist/722g60/gruppernas_artiklar_och_presentationer/1.149935/Artikeltillseminarie2gruppB2.pdf>[Accessed 10 May 2014].

Daughtrey, C.L., Vowles, N.S. and Black, G.S., 2013. The Effects of Membership and Demographics on Consumer Satisfaction and Loyalty in Service Organizations, Services Marketing Quarterly, [e-journal] 34:4, pp.292-308. http://dx.doi.org/10.1080/15332969.2013.827066.

Durmuş, B., Yurtkoru, S. and Çinko, M., 2011. Sosyal Bilimlerde SPSS’le Veri Analizi. 4. Baskı. İstanbul: Beta Yayıncılık.

Fukuyama, F., 1995. Trust: The social virtues and the creation of prosperity. New York: The Free Press.

Gan, C., Cohen, D., Clemes, M., and Chong, E., 2006. A Survey of Customer Retention in the New Zealand Banking Industry, Banks and Bank Systems, Volume 1, Issue 4, pp.83-99.[online] Available at: <https://webcache.googleusercontent.com/search?q> [Accessed 7 October 2012].

Gustafsson, A., Johnson, M.D., and Roos, I., 2005. The Effects of Customer Satisfaction, Relationship Commitment Dimensions, and Triggers on Customer Retention. Journal of Marketing, Vol. 69, October 2005, pp.210-218. Available through: Isik University Library website <http://ezp.isikun.edu.tr:2067/bsi/pdfviewer/pdfviewer?vid=65\&sid=f6c6f6cf-282f-4327-ab18-f946a552abe6\%40sessionmgr4010> [Accessed 9 June 2013]

Hair, J., Anderson, R.E., Tahtam, R.L., and Black, W.C., 1998. Multivariate Data Analysis. Upper Saddle River: Fifth Edition, Prentice Hall.

Hinterhuber, H. H. and Matzler, K. 1998. How to Make Product Development Projects More Successful by Integrating Kano's Model of Customer Satisfaction into Quality Function Deployment. Technovation, [e-journal] 18(1), pp.25-37. Available through: Isik University Library website <http://ezp.isikun.edu.tr:2163/S0166497297000722/1-s2.0-S0166497297000722-main.pdf? tid=445eb290-730e-11e7a658-00000aacb35f\&acdnat=1501189257_0dc0f754f4749812cd70f4fd3759a7cb> [Accessed 23 January 2013]

Kotler, P., 2003. Marketing Management, 11th ed., Upper Saddle River, NJ: Pearson Education International. 
Kotler, P. and Keller, K.L., 2006. Marketing Management, 11th ed., Upper Saddle River, NJ: Prentice Hall.

Mcllroy, A. and Barnett, S., 2000. Building customer relationships: do discount cards work?. Managing Service Quality: An International Journal, [e-journal] Vol. 10 Issue: 6, pp.347-355. https://doi.org/10.1108/09604520010351491.

Nguyen, N., Leclerc, A., and LeBlanc, G., 2013. The Mediating Role of Customer Trust on Customer Loyalty. Journal of Service Science and Management, [e-journal] Vol. 6, pp. 96-109. http://dx.doi.org/10.4236/jssm.2013.61010

Nikhashemi, S.R., Paim, L., Haque, A., Khatibi, A., and Tarofder, A.K., 2013. Internet Technology, Crm and Customer Loyalty: Customer Retention and Satisfaction Perspective. Middle-East Journal of Scientific Research, [e-journal] Vol. 14 (1), pp.79-92. http://dx.doi.org /10.5829/idosi.mejsr.2013.14.1.1984

Nunnally, J., 1979. Psychometric Theory. New York: McGraw Hill.

O'Malley, L., Tynan C., 2000. Relationship marketing in consumer markets; rhetoric or reality?. European Journal of Marketing, [online] Vol. 34, No.7, 2000, pp. 797-815. Available at:

<http://www.emeraldinsight.com_Insight_ViewContentServlet_FilenamePublished_EmeraldFullTextArticle_Pdf_0070340703.pdf> [Accessed 17 March 2014]

Pepić, O., and Duman, T., 2015. Use of Customer Relationship Management (CRM) to achieve marketing goals in companies from Bosnia and Herzegovina. International Conference on Economic and Social Studies, Regional Economic Development - Business Perspectives, Vol. 2 No.2, pp. 225-230, ISSN: 2303-4564, [online] Available at:

<http://acikerisim.bingol.edu.tr:8080/xmlui/bitstream/handle/11472/683/ICESoS'15\%20-Proceedings\%20\%20Book,\%20ss.\%20252258.pdf?sequence=1\#page $=225>$ [Accessed 22 October 2015].

Potter-Brotman, J., 1994. The New Role of Service in Customer Retention. Managing Service Quality: An International Journal, [e-journal] Vol. 4 Issue: 4, pp.53-56. http://dx.doi.org/10.1108/09604529410065298

Preikschas, M.W., Cabanelas, P., Rüdiger, K., Lampón, J.F., 2017. Value co-creation, dynamic capabilities and customer retention in industrial markets. Journal of Business \& Industrial Marketing, [e-journal] Vol. 32 Issue: 3, pp.409-420. http://dx.doi.org/10.1108/JBIM-102014-0215

Ranaweera, C., and Neely, A., 2003. The influence of satisfaction, trust and switching barriers on customer retention in a continuous purchasing setting. International Journal of Operations and Production Management, [e-journal] Vol. 23, No.4, pp.230-248. https://doi.org/10.1108/09564230310489231.

Ranaweera, C., and Prabhu, J., 2003. The influence of satisfaction, trust and switching barriers on customer retention in a continuous purchasing setting. International Journal of Service Industry Management, [e-journal] vol.14, no.4, pp.374-395. http://dx.doi.org/10.1108/09564230310489231.

Reichheld, F. F., and Sasser, W.E., 1990. Zero Defections: Quality Comes to Services, Harvard Business Review, [e-journal]. Available through: Isik University Library website <http://ezp.isikun.edu.tr:2067/bsi/pdfviewer> [Accessed 11 February 2015].

Rust, R. and Zahorik, A., 1993. Customer Satisfaction, Customer Retention and Market Share. Journal of Retailing, [online] Vol. 69, No. 2, pp. 193-215. Available at: <http://dina.com.cn/news/UploadFiles/t8.pdf> [Accessed 12 March 2014].

Shahin, A., n.d. SERVQUAL and Model of Service Quality Gaps: A Framework for Determining and Prioritizing Critical Factors in Delivering Quality Services. [online] Available at: <http://nassar2000.tripod.com/services2007/119.pdf> [Accessed 20 January 2014].

Wayland, R.E. and Paul M.C., 1997. Customer Connections: New Strategies for Growth. Boston: Harvard Business School Press.

Wu, H.H., Tang, Y.T., and Shyu, J.W., 2010. An integrated approach of Kano's model and Importance-Performance Analysis in identifying key success factors. African Journal of Business Management, [online] Vol. 4(15), pp. 3238-3250, Available at: <http://www.academicjournals.org/AJBM> [Accessed 29 December 2014].

Yüksel, A.H., 2017. Innoveadership: Marrying Strategic Leadership with Complexity. In: W.C.X. Wang, ed. 2017. Encyclopedia of Strategic Leadership and Management. Hershey PA: IGI Global. pp.282-295.

Zeithaml, V. A. and Bitner, M. J., 2000. Services Marketing: Integrating Customer Focus Across the Firm. $2^{\text {nd }}$ ed. NJ: McGraw-Hill. 